\title{
An improved method for the establishment of a model of Graves' disease in BALB/c mice
}

\author{
WEI ZHENG ${ }^{*}$, RENFEI WANG* , JIAN TAN, NING LI and ZHAOWEI MENG \\ Department of Nuclear Medicine, Tianjin Medical University General Hospital, Tianjin 300052, P.R. China
}

Received November 17, 2015; Accepted November 25, 2016

DOI: $10.3892 / \mathrm{mmr} .2017 .6181$

\begin{abstract}
The present study aimed to develop a stable Graves' disease (GD) model in BALB/c mice by immunization and electroporation (EP). A total of 90 mice were divided into experimental $(n=50)$, control $(n=20)$ and blank $(n=20)$ groups. The recombinant plasmid pcDNA3.1/thyroid-stimulating hormone (TSH) receptor 268 was constructed and injected into the bilateral gastrocnemius of experimental group mice at weeks 1, 4, 7 and 10. Equal volumes of saline were injected into the control and blank groups at the same time. The experimental and control groups were subjected to EP at the same time and location to enhance immunization. The levels of total serum thyroxine $\left(\mathrm{T}_{4}\right)$ and serum TSH were examined by radioimmunoassay and immunoradiometric assay, respectively. The levels of serum thyrotropin receptor N-terminal (TRAb N) and C-terminal (TRAb C) antibodies were assessed by ELISA. Whole body pertechnetate $\left({ }^{99} \mathrm{TcO}_{4}{ }^{-}\right)$imaging was performed. Mouse weight and thyroid morphology and pathology were analyzed. The GD BALB/c mouse model was successfully established, with a positive rate of $79.17 \%$ (38/48). $\mathrm{T}_{4}$ levels increased from baseline levels of $12.05 \pm 4.23$ to $52.51 \pm 23.58 \mathrm{ng} / \mathrm{ml}$ by week $12(\mathrm{P}<0.0001)$. $\mathrm{TSH}$ levels decreased from baseline levels of $5.53 \pm 2.78$ to $1.43 \pm 0.89 \mu \mathrm{IU} / \mathrm{ml}$ by week $12(\mathrm{P}<0.0001)$. TRAb $\mathrm{N}$ antibody levels increased from baseline levels of $0.006 \pm 0.002$ to $0.278 \pm 0.106 \mathrm{mIU} / \mathrm{ml}$ by week $12(\mathrm{P}<0.0001)$. TRAb C antibody levels increased from baseline levels of $11.111 \pm 2.808$ to $46.701 \pm 26.436$ arbitrary units/ml by week $12(\mathrm{P}<0.0001)$. At week 21, TSH levels remained reduced compared with pre-immunization levels $(\mathrm{P}<0.0001)$. Although $\mathrm{T}_{4}$, and TRAb $\mathrm{N}$ and $\mathrm{C}$ levels decreased, they remained increased compared with preimmunization levels $(\mathrm{P}<0.0001, \mathrm{P}<0.0001$, $\mathrm{P}=0.001)$. There were no significant alterations in antibody
\end{abstract}

Correspondence to: Professor Jian Tan, Department of Nuclear Medicine, Tianjin Medical University General Hospital, 154 Anshan Road, Heping, Tianjin 300052, P.R. China

E-mail: tanpost@163.com

*Contributed equally

Key words: Graves' disease, animal model, thyrotropin receptor levels between the control and blank groups. Following four immunizations, the uptake of ${ }^{99} \mathrm{~m} \mathrm{TcO}_{4}^{-}$by the thyroid was significantly increased in the experimental group. The mean weight of the experimental mice was significantly reduced compared with the control and blank groups (all $\mathrm{P}<0.0001$ ). Furthermore, the thyroid glands of the immunized mice were enlarged and exhibited lymphocyte infiltration, fewer colloid nodules and an increased height of epithelial cells. In conclusion, by injecting recombinant plasmid pcDNA3.1/TSHR268 and EP, a GD mouse model was successfully established.

\section{Introduction}

Thyrotoxicosis is a condition with multiple etiologies, manifestations and potential therapies. The term 'thyrotoxicosis' refers to a clinical state that results from increased thyroid hormone levels in tissues. The most common manifestation is termed Graves' disease (GD). In China, the prevalence of GD is approximately $1.1-1.4 \%$ (1). GD is an organ-specific autoimmune thyroid disease with a genetic predisposition. Typical features of GD include high metabolic syndrome, goiter and Graves' orbitopathy (GO). Patients with GD should be treated with any of the following modalities: Anti Thyroid Drugs (ATDs), radioactive iodine (RAI) therapy, or thyroidectomy. In China, ATD therapy has been the most preferred by physicians, however recent developments have suggested an increase in the use of RAI therapy to reduce the use of ATDs. In GD, the generation of an autoantibody, thyrotrophin receptor antibody (TRAb), against the thyroid-stimulating hormone (TSH) receptor (TSHR) causes continuous stimulation of the thyroid gland and hyperthyroidism $(2,3)$. The precise immunological mechanism of TRAb production, however, remains elusive. Previous studies have indicated that TRAb is detected in the serum of most patients with GD $(4,5)$. TRAb is an important independent risk factor for GD (6). The titer of TRAb influences the duration of ATD therapy and the dose of RAI therapy (7). The establishment of a GD animal model allows the study of its etiology and potential therapeutic targets. In recent years, various animal models of GD have been developed that have demonstrated an autoimmune response to TSHR. Two attempts were made to immunize mice using human TSHR: one via the injection of TSHR-transfected cells simultaneously expressing MHC class II (8), and the other by genetic immunization using TSHR cDNA (9). These immunized mice demonstrated typical phenotypes associated 
with hyperthyroidism, however the response was temporary and TRAb was produced against non-self TSHR. The process of autoantibody production in these mice presumably lacks the persistent abrogation of self-tolerance. The present study investigated an improved method for inducing GD in BALB/c mice by injecting the recombinant plasmid pcDNA3.1/TSHR268 and performing electroporation (EP). This novel method has numerous advantages, including a short model cycle, high success rates, stability and reproducibility. This model may not precisely mimic human disease; however, the present study forms a theoretical basis for further study on the etiology and pathogenesis of GD, and for the development of novel therapeutic strategies.

\section{Materials and methods}

Materials. A total of 90 female BALB/c mice (age, 6-8 weeks; weight, 18-20 g) were obtained from the Institute of Laboratory Animal Sciences, Chinese Academy of Medical Sciences (Beijing, China). All the animals were housed in individual cages with a constant temperature $\left(18-20^{\circ} \mathrm{C}\right)$ and humidity (65-69\%) at 12/12 h light/dark cycle with free access to food and water. The experimental procedures were approved by the animal ethics committee of Tianjin Medical University. EP was performed using an ECM ${ }^{\circledR} 830$ electroporater (BTX; Harvard Apparatus, Holliston, MA, USA). Pertechnetate $\left({ }^{99} \mathrm{TcO}_{4}{ }^{-}\right)$ was produced by a molybdenum technetium generator (China Institute of Atomic Energy, Beijing, China). The mice were imaged using a single-photon emission computer tomography (SPECT) machine (Discovery NM-670; GE Healthcare Life Sciences, Shanghai, China).

Preparation of recombinant plasmid pcDNA3.1/TSHR268. Total RNA was extracted from healthy human thyroid tissue and reverse transcribed. The tissue was obtained from male and female adult patients, during the resection of benign thyroid nodules. The Total RNA extraction kit (Protein and RNA Extraction Kit) and reverse transcription kit (PrimeScript 1st Strand cDNA Synthesis kit) were supplied by Takara Biotechnology Co., Ltd. (Dalian, China). The experiments were performed following the manufacturer's protocol. The experimental procedures and materials were approved by the ethics committee of Tianjin Medical University General Hospital. Human TSHR 164-967 bp (TSHR268) was amplified by polymerase chain reaction (PCR) using the following primer sequences: Forward, 5'-ACGCGAATTCGCCACCAT GGGGTGTTCGTCTCC-3 and reverse, 5'-AGGCGGAT CCCTGATTCTTAAAAGCACAGCAGT-3. The PCR reaction mixture contained: $0.25 \mu 1$ Pyrobest $^{\mathrm{TM}}$ DNA polymerase (Takara Biotechnology Co., Ltd.), $5 \mu 1$ 10X Pyrobest buffer, $4 \mu 1$ 2'-deoxynucleoside 5'-triphosphates mix (2.5 mmol/l), $1 \mu \mathrm{l}$ upstream primer $(20 \mu \mathrm{mol} / \mathrm{l}), 1 \mu \mathrm{l}$ downstream primer (20 $\mu \mathrm{mol} / \mathrm{l}), 2.5 \mathrm{ng}$ template cDNA and deionized water to a final volume of $50 \mu \mathrm{l}$. The cycling conditions were as follows: Pre-denaturation at $94^{\circ} \mathrm{C}$ for $4 \mathrm{~min}$, followed by 30 cycles of denaturation at $94^{\circ} \mathrm{C}$ for $45 \mathrm{sec}$, annealing at $56^{\circ} \mathrm{C}$ for $30 \mathrm{sec}$ and extension at $72^{\circ} \mathrm{C}$ for $1 \mathrm{~min}$, and a final extension step at $72^{\circ} \mathrm{C}$ for $5 \mathrm{~min}$. The PCR product was cloned into the pcDNA3.1 vector by pcDNA3.1/V5-His TOPO TA Expression Kit (Invitrogen; Thermo Fisher Scientific, Inc., Waltham, MA,
USA). The experimental procedure was conducted according to the manufacturer's protocol.

Experimental groups. The BALB/c mice were randomly divided into experimental $(n=50)$, control $(n=20)$ and blank $(n=20)$ groups. Mice were injected with the recombinant plasmid pcDNA3.1/TSHR268 (experimental group) or an equal volume of saline (control and blank groups). Experimental and control group mice were subjected to EP.

Establishment of the GD mouse model. Mice were anesthetized with an intraperitoneal injection of $50 \mathrm{mg} / \mathrm{kg}$ sodium pentobarbital (Shanghai Haling Biotechnology Co., Ltd., Shanghai, China). At weeks 1, 4, 7 and 10, recombinant plasmid pcDNA3.1/TSHR268 $(50 \mu \mathrm{l}, 1 \mathrm{~g} / \mathrm{l})$ was injected into the bilateral gastrocnemius of experimental group mice. An equal volume of saline was injected into the control and blank group mice at the same time. The experimental and control group mice were subjected to EP at the same time and location to enhance immunization. For EP, a pair of electrode needles was injected into the muscle across the site at which the recombinant plasmid was injected. Electric pulses were delivered using an electroporator. A total of three $50 \mathrm{~V}$ pulses and three additional pulses of the opposite polarity were administered at each injection site at a rate of one pulse per $200 \mathrm{msec}$, a frequency of 5 pulses/sec and a duration of $50 \mathrm{msec}(10)$.

$T_{4}$ and TSH measurements. Blood from the angular vein was collected to measure the levels of total serum $\mathrm{T}_{4}$ and serum TSH using radioimmunoassay and immunoradiometric kits, respectively (Beijing North Institute of Biotechnology, Beijing, China) 7 to 10 days after each immunization and every three weeks until week 21 .

ELISA for measuring TRAbN-terminal $(N)$ and C-terminal $(C)$. Blood from the angular vein was collected to measure the levels of TRAb N and C by ELISA at the same time points as above. Thyroid-stimulating antibody (TSAb) was used in the $\mathrm{N}$ method and thyroid stimulation blocking antibody (TSBAb) was used in the $\mathrm{C}$ method, as respective antigens. A total of two ELISA methods for the detection of TSAb and TSBAb have been established and evaluated by our laboratory (11). The absorbance value $\mathrm{A}_{450}$ served as the quantitative parameter to reflect the levels of TRAb. TRAb C levels were measured in arbitrary units per milliliter (AU/ml) (12).

${ }^{99 m} \mathrm{TcO}_{4}$ radioactive isotope imaging. Whole body ${ }^{99 \mathrm{~m}} \mathrm{TcO}_{4}$ imaging was performed at weeks 0,12 and 21 . A total of three mice from each group were randomly selected and anesthetized with pentobarbital. ${ }^{99 \mathrm{~m}} \mathrm{TcO}_{4}{ }^{-}$was intraperitoneally injected into each mouse $(37 \mathrm{MBq} / 0.1 \mathrm{ml})$. Scintigraphy was performed 10 min later using a SPECT machine. A low-energy universal collimator was used for imaging. The imaging conditions were as follows: Energy peak, $140 \mathrm{keV}$; matrix, 128x256; magnification, 3.0; and counts, $3 \times 10^{5}$.

Weight, thyroid morphology and pathology analysis. All mice were weighed 7 to 10 days following each immunization and every three weeks until week 21 . They were subsequently sacrificed by cervical vertebra dislocation at the end of 


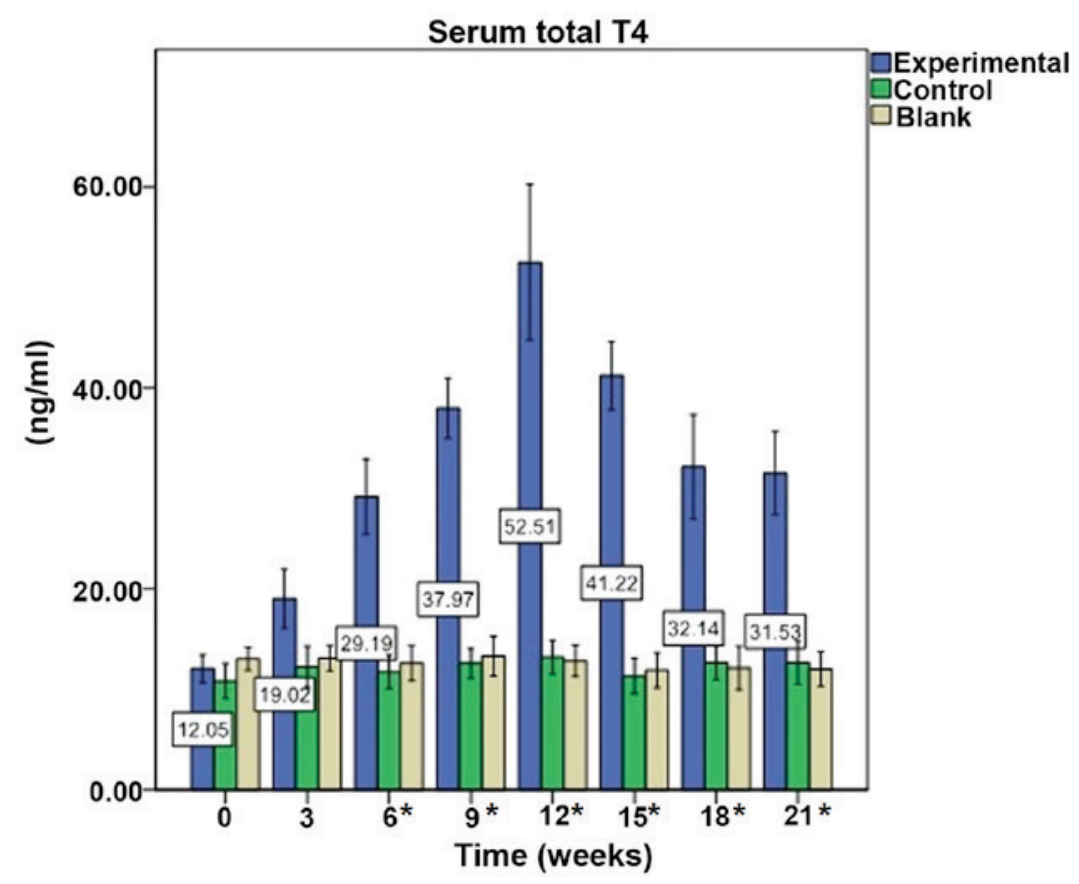

Figure 1. Immunization elevates total serum $\mathrm{T}_{4}$ levels. Prior to immunization, mean levels of $\mathrm{T}_{4}$ in the experimental, blank and control groups were similar. Following immunization, mean levels of $\mathrm{T}_{4}$ in experimental mice increased gradually. Upon cessation of immunization, $\mathrm{T}_{4}$ levels in the experimental group decreased slightly; however, they remained significantly elevated compared with pre-immunization levels. There were no significant alterations in $\mathrm{T}_{4}$ levels in the control and blank groups during the experimental process. Data are presented as the mean \pm standard deviation. ${ }^{*} \mathrm{P}<0.05$. $\mathrm{T}_{4}$, thyroxine.

week 21. The thyroid glands were removed and fixed with $10 \%$ formalin. After one week, the tissue was embedded in paraffin blocks, sectioned and stained with hematoxylin and eosin for analysis (13).

Statistical analysis. Data were analyzed using an independent samples t-test or one-way analysis of variance followed by a least significant difference post hoc test. SPSS software version 19.0 (IBM SPSS, Armonk, NY, USA) was used to analyze the data. Data are expressed as the mean \pm standard deviation or number $(\%) . \mathrm{P}<0.05$ was considered to indicate a statistically significant difference.

\section{Results}

Induction of GD in mice. During the course of the experiment, two mice in the experimental group and one in the blank group died. Prior to the experiment, $\mathrm{T}_{4}$, and TRAb $\mathrm{N}$ and $\mathrm{C}$ levels of all mice in the experimental group were within the same range as those in the control and blank groups. At the end of the immunization protocol (week 12), 38 of the 48 mice in the experimental group had increased levels of $\mathrm{T}_{4}$, and TRAb $\mathrm{N}$ and $\mathrm{C}$. All 38 mice demonstrated reduced levels of TSH. The rate of disease induction was therefore $79.17 \%$.

Immunization elevates serum $T_{4}$ levels. Prior to immunization (week 0), baseline mean levels of $\mathrm{T}_{4}$ in the experimental mice were $12.05 \pm 4.23 \mathrm{ng} / \mathrm{ml}$. Following the first immunization, the mean levels of $\mathrm{T}_{4}$ increased slowly and peaked following the fourth immunization at week 12, where $\mathrm{T}_{4}$ was $52.51 \pm 23.58 \mathrm{ng} / \mathrm{ml}(\mathrm{P}<0.0001) . \mathrm{T}_{4}$ levels decreased from weeks 15 to 21 ; however, they remained significantly increased compared with pre-immunization levels (all $\mathrm{P}=0.000)$. $\mathrm{T}_{4}$ levels in the control group were $13.21 \pm 3.73 \mathrm{ng} / \mathrm{ml}$ at week 12 vs. $10.84 \pm 3.79 \mathrm{ng} / \mathrm{ml}$ at week $0(\mathrm{P}=0.593)$, and in the blank group were $12.84 \pm 3.36 \mathrm{ng} / \mathrm{ml}$ at week $12 \mathrm{vs} .13 .03 \pm 2.47 \mathrm{ng} / \mathrm{ml}$ at week $0(\mathrm{P}=0.892)$. There were no significant alterations in $\mathrm{T}_{4}$ levels in the control and blank groups during the experiment (Fig. 1).

Immunization reduces serum TSH levels. Prior to immunization (week 0), baseline mean levels of serum TSH in the experimental mice were $5.53 \pm 2.78 \mu \mathrm{IU} / \mathrm{ml}$. Following the first immunization, the mean levels of TSH declined (all $\mathrm{P}<0.0001$ ). During the course of the experiment, TSH levels fluctuated; however, they remained reduced compared with pre-immunization levels (all $\mathrm{P}<0.0001)$. TSH levels in the control group were $5.35 \pm 2.17 \mu \mathrm{IU} / \mathrm{ml}$ at week 12 vs. $5.16 \pm 2.70 \mu \mathrm{IU} / \mathrm{ml}$ at week 0 $(\mathrm{P}=0.969)$, and in the blank group were $5.25 \pm 2.72 \mu \mathrm{IU} / \mathrm{ml}$ at week 12 vs. $5.10 \pm 1.99 \mu \mathrm{IU} / \mathrm{ml}$ at week $0(\mathrm{P}=0.960)$. There were no significant alterations in serum TSH levels in the control and blank groups (Fig. 2).

Immunization elevates TRAb $N$ and $C$ levels. Prior to immunization (week 0), baseline mean levels of serum TRAb $\mathrm{N}$ and $\mathrm{C}$ in experimental mice were $0.006 \pm 0.002 \mathrm{mIU} / \mathrm{ml}$ and $11.111 \pm 2.808 \mathrm{AU} / \mathrm{ml}$, respectively. Following the first immunization, the mean levels of TRAb $\mathrm{N}$ and $\mathrm{C}$ increased steadily. Following the third immunization at week nine, TRAb N and C levels peaked at $0.306 \pm 0.146 \mathrm{mIU} / \mathrm{ml}$ and 51.566 $\pm 37.357 \mathrm{AU} / \mathrm{ml}$, respectively (all $\mathrm{P}<0.0001$ ). From the fourth immunization (week 12) to the end of the experiment (week 21), the mean levels of TRAb $\mathrm{N}$ and $\mathrm{C}$ decreased; however, they remained significantly increased compared with pre-immunization levels (TRAb C at week 21, $\mathrm{P}=0.001$, 


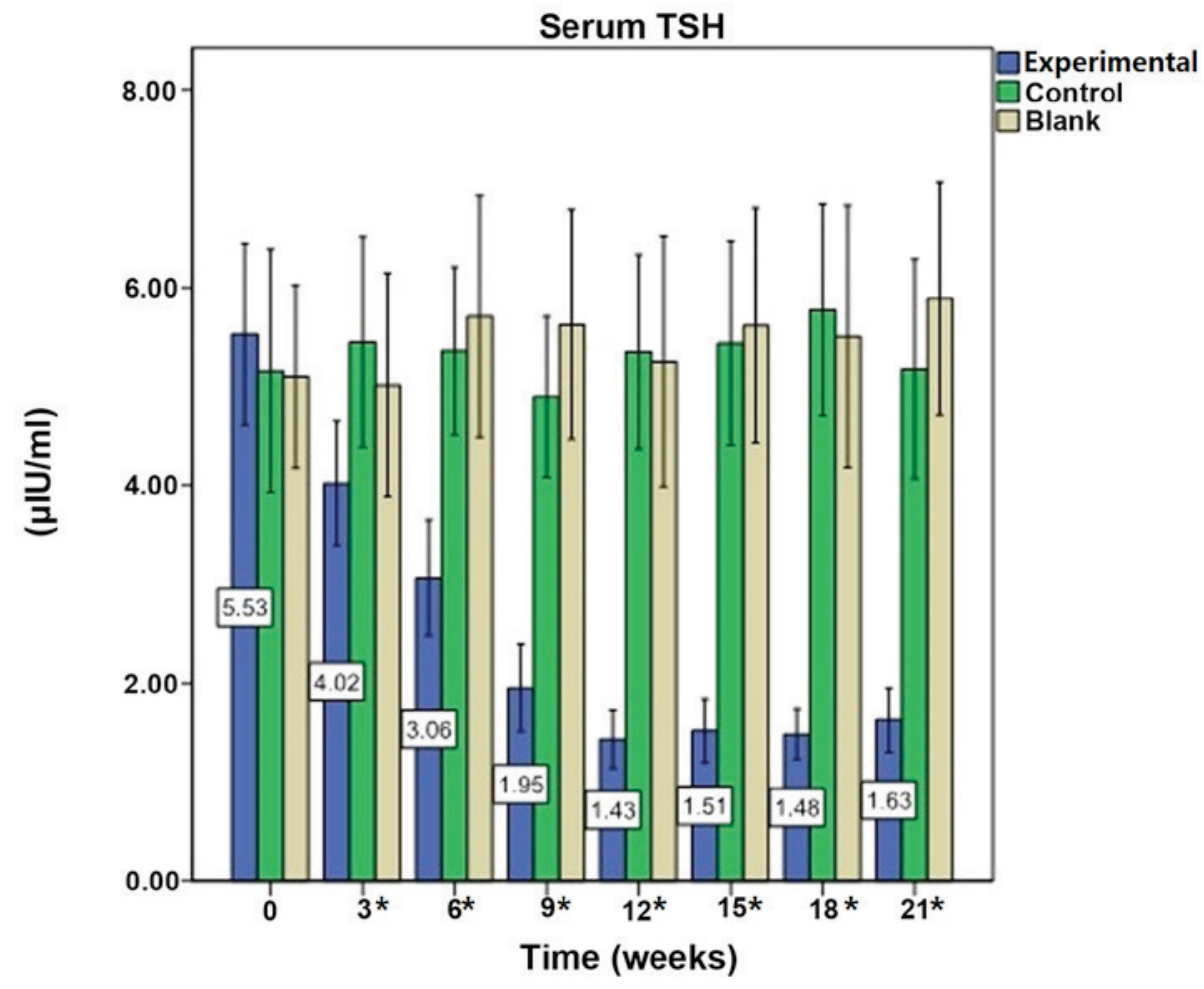

Figure 2. Immunization reduces serum TSH levels. Prior to immunization, mean levels of serum TSH in the experimental, blank and control groups were similar. Following the first immunization, mean levels of TSH in experimental mice reduced until the fourth immunization at week 12 . TSH levels fluctuated following cessation of immunization; however, they remained reduced compared with pre-immunization levels. There were no significant alterations in serum TSH levels in the control and blank groups. Data are presented as the mean \pm standard deviation. ${ }^{~} \mathrm{P}<0.05$ vs. control. TSH, thyroid-stimulating hormone.

$\mathbf{A}$

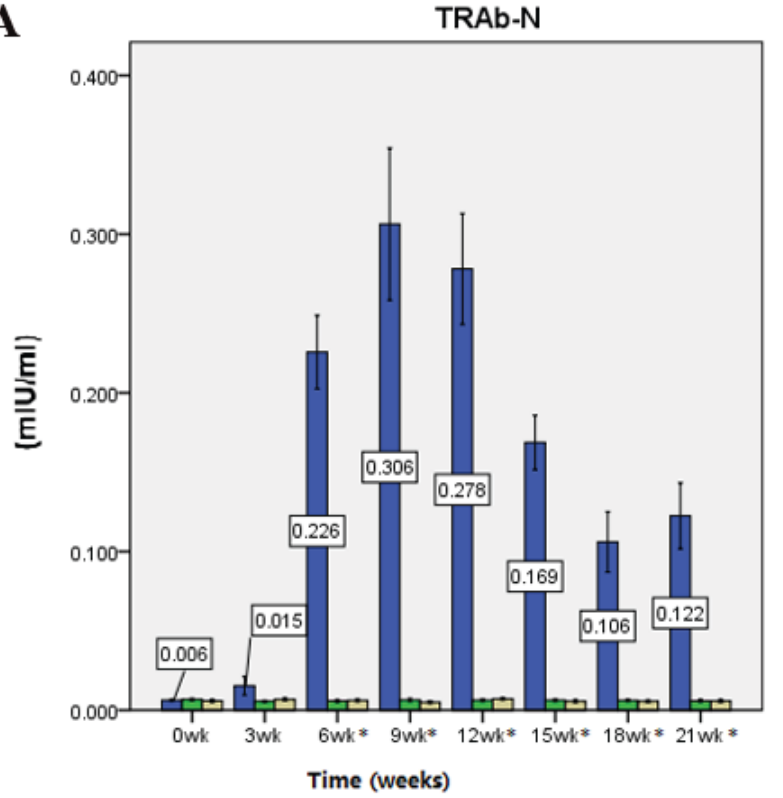

B

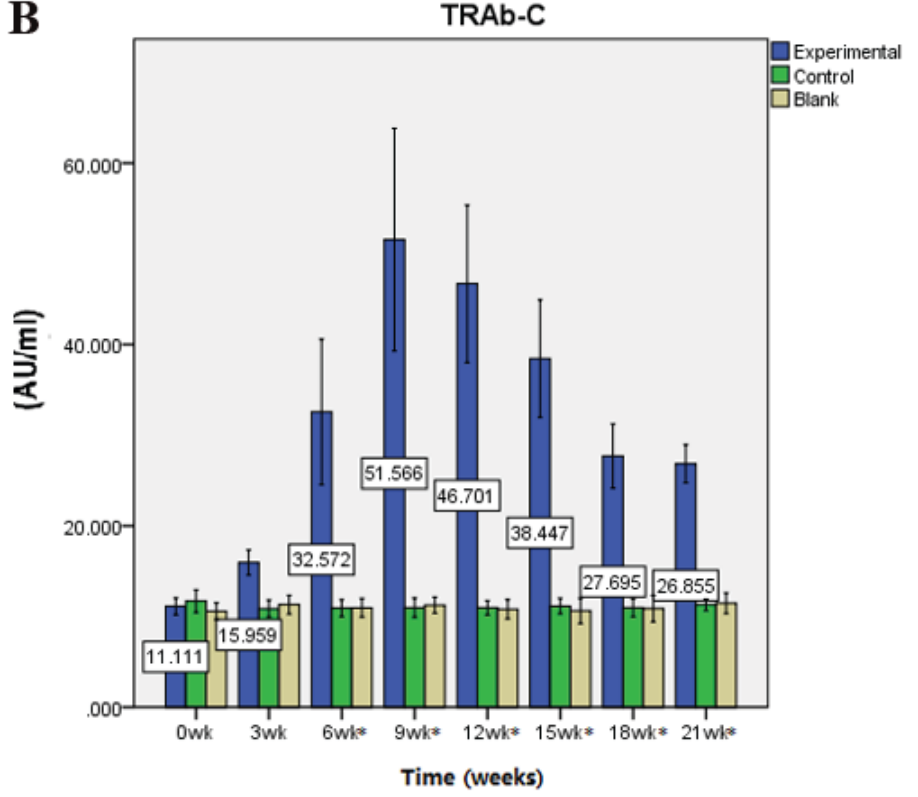

Figure 3. Immunization elevates TRAb N and C levels. (A) Mean levels of TRAb N, the thyroid-stimulating hormone receptor-stimulating antibody, markedly increased in the experimental group compared with the control and blank groups following immunization at week six. (B) Mean levels of TRAb C increased synchronously with TRAb N; however, at a more gradual rate. Following the third immunization at week nine, TRAb N and TRAb C levels peaked. Upon cessation of immunization, mean levels of TRAb N and C decreased; however, they remained significantly increased compared with pre-immunization levels. There were no significant alterations in the control and blank groups during the experimental process. Data are presented as the mean \pm standard deviation. ${ }^{*} \mathrm{P}<0.05$ vs. control. TRAb N, thyroid-stimulating hormone receptor $\mathrm{N}$-terminal; TRAb C, thyroid-stimulating hormone receptor $\mathrm{C}$-terminal.

the rest $\mathrm{P}<0.0001)$. TRAb N levels in the control group were $0.006 \pm 0.002 \mathrm{mIU} / \mathrm{mlatweek} 9 \mathrm{vs} .0 .007 \pm 0.002 \mathrm{mIU} / \mathrm{mlatweek}$ $0(\mathrm{P}=0.520)$, and in the blank group were $0.005 \pm 0.002 \mathrm{mIU} / \mathrm{ml}$ at week 9 vs. $0.006 \pm 0.002 \mathrm{mIU} / \mathrm{ml}$ at week $0(\mathrm{P}=0.885)$. TRAb C levels in the control group were $10.97 \pm 2.35 \mathrm{AU} / \mathrm{ml}$ at week 9 vs. $11.69 \pm 2.78 \mathrm{AU} / \mathrm{ml}$ at week $0(\mathrm{P}=0.933)$, and 


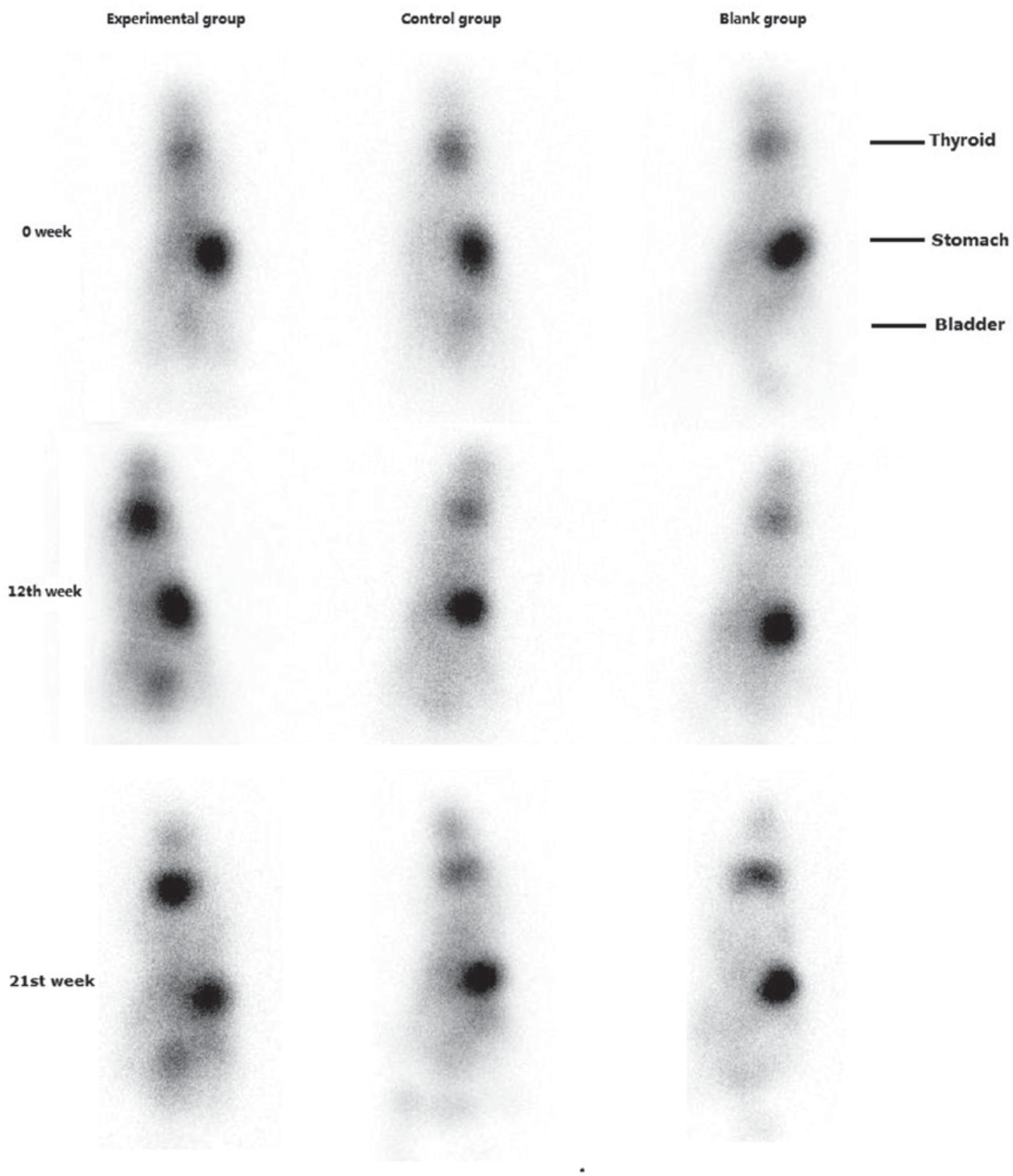

Figure $4 .{ }^{99 \mathrm{~m}} \mathrm{TcO}_{4}^{-}$radioactive isotope imaging. Prior to immunization at week 0 , the uptake of ${ }^{99 \mathrm{~m}} \mathrm{TcO}_{4}^{-}$by the thyroid was similar between the experimental, blank and control group mice. Following four immunizations (at week 12), increased uptake of ${ }^{99} \mathrm{TcO}_{4}{ }^{-}$by the thyroid was observed in the experimental group. At week 21, this uptake remained increased compared with pre-immunization levels. There were no significant alterations in ${ }^{99 \mathrm{~m}} \mathrm{TcO}_{4}^{-}$uptake in the control and blank groups. ${ }^{99} \mathrm{TcO}_{4}^{-}$, pertechnetate.

in the blank group were $11.25 \pm 1.91 \mathrm{AU} / \mathrm{ml}$ at week 9 vs. $10.59 \pm 1.99 \mathrm{AU} / \mathrm{ml}$ at week $0(\mathrm{P}=0.939)$. There were no significant alterations in TRAb $\mathrm{N}$ and $\mathrm{C}$ levels in the control and blank groups (Fig. 3).

${ }^{99}{ }^{m} \mathrm{TcO}_{4}$ radioactive isotope imaging. There were no significant differences in thyroid ${ }^{99}{ }^{9} \mathrm{TcO}_{4}^{-}$uptake between the three groups prior to immunization. Following the fourth immunization (week 12), the uptake of ${ }^{99} \mathrm{TcO}_{4}^{-}$by the thyroid was increased in the experimental group. At week 21, this remained increased compared with pre-immunization levels. There were no significant alterations in ${ }^{99} \mathrm{mcO}_{4}{ }^{-}$thyroid uptake in the control and blank groups (Fig. 4).
Weight, thyroid morphology and pathology analysis. At week 0 , the mean weights of mice in the three groups were similar. The weight of mice increased steadily during the experiment in all groups. At week 21, the mean weight of the experimental mice was significantly reduced compared with the blank and control groups (Table I).

The thyroid glands from experimental group mice exhibited diffuse enlargement with hypertrophy, unlike the blank and control mice (Fig. 5). Examination of the thyroid tissue via microscopy revealed lymphocyte infiltration, fewer colloid nodules and an increase in the height of epithelial cells in experimental mice compared with blank and control group mice (Fig. 6). 


\section{Discussion}

The immunological processes involved in autoimmune thyroid disease, including GD, are hypothesized to be mediated primarily by antibodies, similarly to other autoimmune diseases (14). Hyperactivity of the thyroid gland is the result of thyroid-stimulating antibodies, which are now considered to recognize and activate the TSHR. One of the unique characteristics of GD is the presence of TRAb, which is detectable in the serum of the majority of patients with the disease, and leads to hyperplasia and hyperfunctioning of the thyroid gland due to activation of the thyrotropin receptor $(4,5,15)$. Our previous study demonstrated that, as one of the most important risk factors for GD, TRAb influenced prognosis and treatment efficacy, particularly in female patients (16). A total of three varieties of TRAb are present in most GD patients: TSAb, TSBAb and a neutral antibody. TSAb and TSBAb bind to the $\mathrm{N}$ - and C-terminal regions of the TSHR extracellular domain, respectively. It is hypothesized that TSAb serves a central role in the pathogenesis of GD, by stimulating TSH-mediated activation of thyroid function. However, TSBAb may act as a weak TSH agonist to induce hypothyroidism by preventing TSH from binding to the receptor. The neutral TSHR antibody does not block TSH binding or action (17). Previous studies have indicated that TSBAb may be the precursor form of TSAb (18).

The establishment of an animal model of GD contributes to the investigation of its etiology, pathogenesis and potential therapeutic targets. Following decades of developments, animal models of GD have greatly improved. However, limitations of GD mouse models include the complex model preparation process, low success rate and poor reproducibility. An ideal GD mouse model should be spontaneous, reproducible and have a high disease incidence in a variety of mouse strains (19). Thus far, the common features of all successful GD models include TSHR expression, immune system stimulation via repeated injections.

In the present study, following four immunizations, 38 of $48 \mathrm{BALB} / \mathrm{c}$ mice $(79.17 \%)$ developed hyperthyroidism, a percentage that is consistent with or greater than previous studies (20-23). All hyperthyroid mice demonstrated increased serum $\mathrm{T}_{4}, \mathrm{TRAb} \mathrm{N}$ and $\mathrm{C}$ levels, and reduced TSH and weight levels. It was observed that TRAb N levels markedly increased following the second immunization at week 6 , and peaked at week 9. TRAb C levels demonstrated a similar trend; however, the increase was more gradual. Under the stimulation of TRAb, serum $\mathrm{T}_{4}$ levels increased gradually and peaked following the fourth immunization at week 12 . Over the same period, serum TSH levels declined gradually. Following the fourth immunization, serum TSH levels stabilized. Following cessation of immunization, serum $\mathrm{T}_{4}$ and TRAb levels decreased slightly; however, at the end of the experiment, they remained significantly increased compared with pre-immunization levels. The uptake of ${ }^{99} \mathrm{TcO}_{4}^{-}$by the thyroid increased significantly in immunized mice. Compared with the control and blank groups, mice in the experimental group were emaciated and exhibited enlarged thyroid glands. Examination of the thyroid tissue via microscopy revealed lymphocyte infiltration, fewer colloid nodules and an increase in the height of epithelial cells in the experimental mice compared with the blank and control groups. All of the above are characteristic of GD, thus 

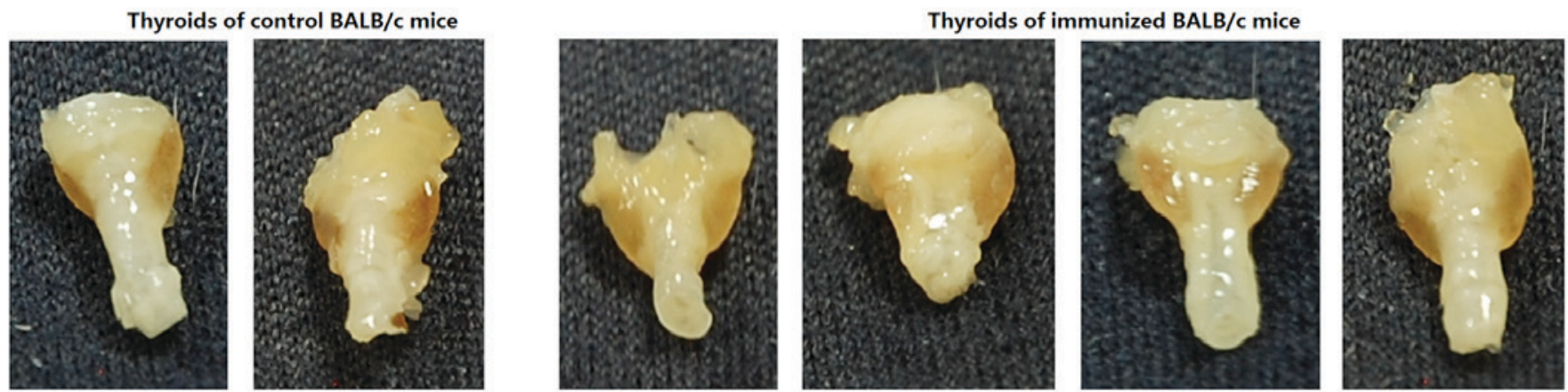

Figure 5. Thyroid morphology analysis. Representative images of the thyroids of control and immunized BALB/c mice. Following immunization, the thyroid glands from hyperthyroid mice were enlarged compared with the thyroid glands from control mice, a feature that may have been induced by the thyroptrophin receptor antibody.
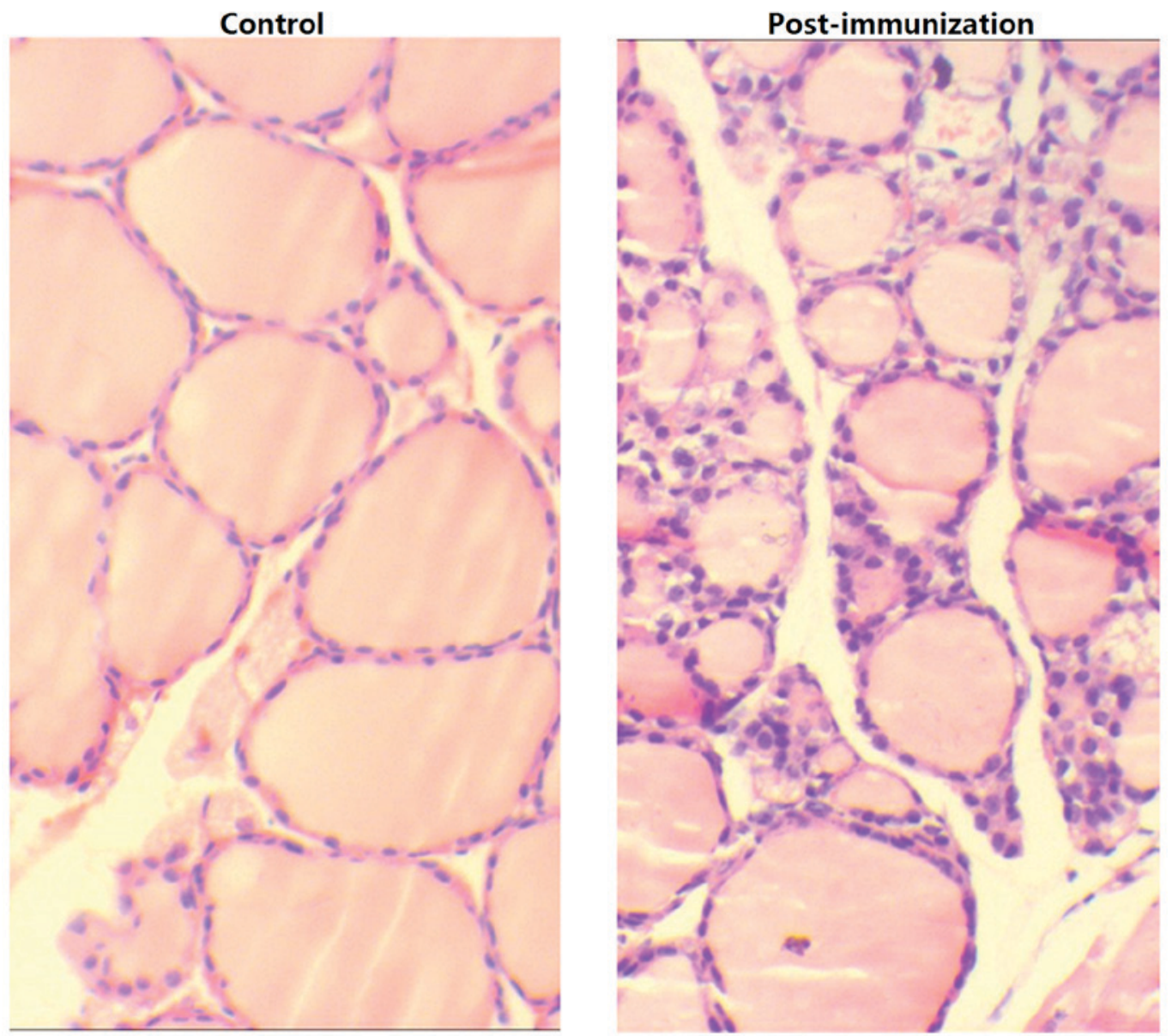

Figure 6. Thyroid pathology analysis. Frozen sections of the thyroid glands from control and immunized mice were stained with hematoxylin and eosin. Examination of the thyroid tissue via microscopy revealed lymphocyte infiltration, fewer colloid nodules and an increase in the height of epithelial cells in experimental compared with control mice. Magnification, x200.

indicating the establishment of a successful of model of the disease. Furthermore, the increased levels of TRAb C support the hypothesis that TSBAb may be the precursor form of TSAb.

It is widely accepted that the study of animal models of disease provides an improved understanding of the underlying pathogenesis, and may be used for evaluating novel therapeutic strategies. An appropriate animal model of GD would include the following features: i) Elevated $\mathrm{T}_{4}$ and/or reduced TSH levels, ii) TSHR-associated biologically active antibodies, iii) alterations in thyroid architecture, iv) lymphocytic thyroiditis, v) clinical signs of hyperthyroidism including weight loss, vi) orbital alterations similar to those in thyroid eye disease, and vii) lymphocytic infiltration in the pretibial skin (24). With the exception of pathological alterations of eyes and pretibial skin, the additional five clinical characteristics were observed in the model established in the present study.

In conclusion, the present study demonstrated an improved animal model of GD in which repeated intramuscular injection 
of recombinant plasmid pcDNA3.1/TSHR268 and EP in vivo efficiently induced TRAb with thyroid stimulating activity and hyperthyroidism. This novel method has the advantages of a short modeling cycle, high induction rate, and good stability and reproducibility. This model may not precisely mimic human disease, and therefore requires further examination; however, based on these findings, it may be possible to further investigate the etiology and pathogenesis of GD, and develop novel ideas for the clinical treatment of this disease.

\section{Acknowledgements}

This paper is supported by the National Natural Science Foundation of China (grant no. 81601523 and 81501510).

\section{References}

1. Teng W, Shan Z, Teng X, Guan H, Li Y, Teng D, Jin Y, Yu X, Fan C, Chong W, et al: Effect of iodine intake on thyroid diseases in China. N Engl J Med 354: 2783-2793, 2006.

2. Rees Smith B, McLachlan SM and Furmaniak J: Autoantibodies to the thyrotropin receptor. Endocr Rev 9: 106-121, 1988.

3. Rapoport B, Chazenbalk GD, Jaume JC and McLachlan SM: The thyrotropin (TSH) receptor: Interaction with TSH and autoantibodies. Endocr Rev 19: 673-716, 1998.

4. Andrade VA, Gross JL and Maia AL: Serum thyrotropin-receptor autoantibodies levels after I therapy in Graves' patients: Effect of pretreatment with methimazole evaluated by a prospective, randomized study. Eur J Endocrinol 151: 467-474, 2004.

5. Takasu N, Kamijo K, Sato Y, Yoshimura H, Nagata A and Ochi Y: Sensitive thyroid-stimulating antibody assay with high concentrations of polyethylene glycol for the diagnosis of Graves' disease. Clin Exp Pharmacol Physiol 31: 314-319, 2004.

6. McKenna TJ: Graves' disease. Lancet 357: 1793-1796, 2001.

7. Ross DS, Burch HB, Cooper DS, Greenlee MC, Laurberg P, Maia AL, Rivkees SA, Samuels M, Sosa JA, Stan MN and Walter MA: 2016 American thyroid association guidelines for diagnosis and management of hyperthyroidism and other causes of thyrotoxicosis. Thyroid 26: 1343-1421, 2016.

8. Shimojo N, Kohno Y, Yamaguchi K, Kikuoka S, Hoshioka A, Niimi H, Hirai A, Tamura Y, Saito Y, Kohn LD and Tahara K: Induction of Graves-like disease in mice by immunization with fibroblasts transfected with the thyrotropin receptor and a class II molecule. Proc Natl Acad Sci USA 93: 11074-11079, 1996.

9. Costagliola S, Many MC, Denef JF, Pohlenz J, Refetoff S and Vassart G: Genetic immunization of outbred mice with thyrotropin receptor cDNA provides a model of Graves' disease. J Clin Invest 105: 803-811, 2000.
10. Vicat JM, Boisseau S, Jourdes P, Lainé M, Wion D, Bouali-Benazzouz R, Benabid AL and Berger F: Muscle transfection by electroporation with high-voltage and short-pulse currents provides high-level and long-lasting gene expression. Hum Gene Ther 11: 909-916, 2000.

11. Li N, Fang P, Zhang Y and Li S: A novel human TSHR antibody ELISA using recombinant extracellular domain fragments of human TSH receptor as antigen and initial clinical evaluation. Chin J Nucl Med 29: 348-351, 2009.

12. Olesen H: Properties and units in the clinical laboratory sciences. I. Syntax and semantic rules (recommendation 1995). International union of pure and applied chemistry (IUPAC) and international federation of clinical chemistry (IFCC). Eur J Clin Chem Clin Biochem 33: 627-636, 1995.

13. Hine IF: Block staining of mammalian tissues with hematoxylin and eosin. Stain Technol 56: 119-123, 1981.

14. Morshed SA, Latif R and Davies TF: Delineating the autoimmune mechanisms in Graves' disease. Immunol Res 54: 191-203, 2012.

15. Marino M, Chiovato L and Pinchera A: Graves' disease. In: De Groot LJ, Jameson JL (eds): Endocrinology eds, 5th edition. Philadelphia, Elsevier Saunders 1979-1994, 2006.

16. Zheng W, Tan J, Zhang G, Meng Z and Wang R: Analysis of ${ }^{131}$ I therapy and correlation factors of Graves' disease patients: A 4-year retrospective study. Nucl Med Commun 33: 97-101, 2012.

17. Morshed SA, Latif R and Davies TF: Characterization of thyrotropin receptor antibody-induced signaling cascades. Endocrinology 150: 519-529, 2009.

18. Ochi Y, Kajita Y, Hachiya T and Hamaoki M: A novel hypothesis for the etiology of Graves' disease: TSAb may be thyroid stimulating animal IgG-like hormone and TBAb may be the precursor of TSAb. Med Hypotheses 78: 781-786, 2012.

19. Nagayama Y: Animal models of Graves' hyperthyroidism. Endocr J 52: 385-394, 2005.

20. Ye F, Shi B, Wu X, Hou P, Gao L, Ma X, Xu L and Wu L: Experience with lentivirus-mediated CD40 gene silencing in a mouse model of Graves' disease. J Endocrinol 208: 285-291, 2011.

21. Kaneda T, Honda A, Hakozaki A, Fuse T, Muto A and Yoshida T: An improved Graves' disease model established by using in vivo electroporation exhibited long-term immunity to hyperthyroidism in BALB/c mice. Endocrinology 148: 2335-2344, 2007.

22. Nagayama Y, Kita-Furuyama M, Ando T, Nakao K, Mizuguchi H, Hayakawa T, Eguchi K and Niwa M: A novel murine model of Graves' hyperthyroidism with intramuscular injection of adenovirus expressing the thyrotropin receptor. J Immunol 168: 2789-2794, 2002.

23. Wu LP, Shi BY, Xun LR, Guo LY, Yang J and Xu L: An exploration of induction methodology and experimental duration of Graves disease animal model. Zhonghua Nei Ke Za Zhi 51: 793-797, 2012 (In Chinese)

24. Ludgate M: Animal models of Graves' disease. Eur J Endocrinol 142: 1-8, 2000. 